\title{
Pesquisa-ação em uma escola sócio-construtivista: as relações humano-natureza no ensino de ciências
}

\author{
Tiago Silva Alves Muniz \\ Licenciatura Plena em Ciências Biológicas \\ Universidade Federal Rural do Rio de Janeiro \\ \tiago.samuniz@gmail.com
}

Recebido em 5 de agosto de 2016

Aceito em 25 de novembro de 2016

\begin{abstract}
Resumo:
Esta pesquisa foi realizada em uma escola do setor privado, localizada no município de Nova Iguaçu, Rio de Janeiro, que possui uma abordagem sócio-construtivista seguindo ainda a linha da Pedagogia Waldorf nos anos iniciais. A fim de investigar como se manifesta a relação ser humano/ natureza/ outros animais nos educandos, que se discute aqui é a necessidade de contextualização entre estes eixos assim como a (re)inserção do homem no ambiente, para que as leituras de mundo possam compreender a relação causa/consequência das atitudes do ser humano e de razões morais que movem suas ações. Foi observado, entre os alunos dos anos iniciais do ensino fundamental II, recém saídos do ensino waldorf, uma formação humanística, e nos anos finais do ensino médio, uma formação para o vestibular.
\end{abstract}

Palavras-chave: Prática de ensino em ciências; Educação ambiental; Didática.

\section{Action-research in a social constructivist school: the human-nature relationships in science teaching}

\begin{abstract}
:
This research was conducted in a school of the private sector, in the municipality of Nova Iguaçu, Rio de Janeiro, which has a socio-constructivist approach and also follows the line of Waldorf education in the early years. In order to investigate how the relationship human/ Nature/ other animals is expressed among students, here is discussed the need for contextualization between these axes as well as to (re-)insertion of the man in the environment, so that readings of the world may understand the cause / result of the attitudes of the human and moral reasons that drive their actions. It was observed among students in the early years of elementary school II, recently came from the waldorf school, a humanistic education and in the final high school years, training for college entrance.
\end{abstract}

Keywords: Teaching practice in science; Environmental education; Didactics.

\section{Investigación-acción en una escuela de constructivismo social: las relaciones humano-naturaleza en la enseñanza de ciencias}

\section{Resumen:}

Esta investigación se llevó a cabo en una escuela del sector privado, en el municipio de Nova Iguaçu, RIo de Janeiro, que tiene un enfoque socio-constructivista aún siguiendo la línea de la educación Waldorf en los primeros años. Con el fin de investigar cómo se expresa la relación humana / 
Naturaleza / otros animales en los estudiantes, aquí es discutido la necesidad de contextualización entre estes puntos, así como a la (re) inserción del hombre en el medio ambiente, para que las lecturas del mundo entendan la causa / consecuencia de las actitudes de los motivos humanos y morales que llevan a sus acciones. Se observó en los estudiantes de los primeros años de la escuela primaria II, recién salido de la escuela waldorf, una educación humanista y los años finales de la escuela secundaria, la formación de ingreso a la universidad.

Palabras clave: Práctica de la enseñanza de la ciência; Educación ambiental; Didáctica.

\section{INTRODUÇÃO}

A pesquisa-ação aqui realizada é oriunda dos estudos realizados em Educação Ambiental (GUIMARÃES, 2004; LOUREIRO, 2007) e Direitos Animais (SINGER, 1975; FRANCIONE, 2000; REGAN, 2006) que culminaram na palestra "O antropocentrismo na escola: uma análise abolicionista" apresentada na Câmara Municipal do Rio de Janeiro no evento "Quarta Animal". A partir da pesquisa teórica, a prática aqui executada visa conhecer como o ensino de ciências contribui para essa instrumentalização da natureza e dos animais. Através do livro didático abordagens fragmentadas de paisagem natural/modificada proporcionam quais cuidados para com os animais e natureza? Como manifestações de visão utilitarista do meio ambiente e dos animais contribuem para o desenvolvimento do educando? O objetivo deste trabalho é entender, de acordo com as leituras de mundo de cada educando, como se manifestam as relações de ser humano / natureza / outros animais. Os envolvidos no público-alvo são: professores da disciplina de ciências naturais (biologia); coordenadores pedagógicos; diretora da escola e alunos da escola em questão.

Esta pesquisa foi realizada em uma escola do setor privado, localizada no município de Nova Iguaçu, Rio de Janeiro. A escolha desta se deu devido a sua abordagem diferenciada seguindo as linhas da Pedagogia Waldorf e do sócio-construtivismo. A Pedagogia Waldorf é diferenciada das demais pedagogias em seus pontos de vista, de forma a demonstrar a sua estruturação dentro de um contexto filosófico, pedagógico e organizacional (STEINER, LANZ e CARDOSO, 2007). Assim, a questão de pesquisa que guiou as atividades reflexões aqui expostas foi: como se manifesta a relação do ser humano / natureza / outros animais na escola sócio-construtivista? A fim de gerar autorreflexão nos educandos sobre o tema realizou-se um levantamento de concepções dos alunos na referida escola, sendo realizadas etapas de observador, observador-participante e entrevistas com os professores de biologia, coordenadores e diretora do colégio. 
A construção do ser humano, baseado em Piaget e em Vygostky, lida diretamente com os processos do desenvolvimento do indivíduo construindo o conhecimento a partir das faixas etárias (observado a partir dos estágios do desenvolvimento genético-cognitivo) e do contexto social e internalização (formação das estruturas comportamentais). Segundo a perspectiva sócio-construtivista, Carretero (1997) pontua que:

A idéia que sustenta que o indivíduo - tanto nos aspectos cognitivos quanto sociais do comportamento como nos afetivos - não é um mero produto do ambiente nem um simples resultado de suas disposições internas, mas, sim, uma construção própria que vai se produzindo, dia a dia, como resultado da interação entre esses dois fatores. Em consequência, segundo a posição construtivista, o conhecimento não é uma cópia da realidade, mas, sim, uma construção do ser humano (CARRETERO, 1997).

O antropocentrismo (do grego anthropos, "humano"; e kentron, "centro"), legitima o usufruto dos serviços ambientais de forma intensa, de modo que, em escala global, a espécie humana exerce o papel de dominadora do ambiente que o cerca. A esta concepção antropocêntrica de mundo, somos subordinados. E, ao externalizar o conceito de meio ambiente - pensando que este "é tudo que nos cerca", nos enquadramos alheios à realidade ambiental. Conforme abordado por Muniz e Bachinski (2012), a relação de dominação do homem sobre a natureza é, ante de qualquer argumentação, determinada pela perspectiva vigente e, afirmada em razões 1) culturais, 2) históricas e 3) sociais. A concepção bíblica, em razão cultural (1), autoriza a utilização do ambiente a bel-prazer quando dispõe: “Frutificai, $e$ multiplicai-vos, e enchei a terra, e sujeitai-a; e dominai sobre os peixes do mar, e sobre as aves dos céus, e sobre todo o animal que se move sobre a terra" Gênesis (1:20-28)

Esta concepção bíblica segue como principal referência até a primeira metade do século XVII, quando Descartes publica suas obras baseadas na teoria do animal-machine. Sobre esta ideia, na qual os animais funcionariam como máquinas, relógios desprovidos de capacidades de sentir dor ou sentimentos, Levai (2007) diz que: “o filósofo René Descartes defendia a teoria do animal machine, sugerindo que os bichos eram meros autômatos incapazes de raciocinar ou de sentir dor, eis que suas reações constituíam apenas reflexos a estímulos externos" (LEVAI, 2007).

Conhecendo basicamente a Teoria da Pedagogia Waldorf, buscaremos entender as relações de que forma os professores da área de 'Ciências Naturais' e coordenadores pedagógicos entendem a relação entre os alunos da escola e os animais, já que a escola possui um discurso sobre a espiritualidade buscamos entender se esta é estendida aos 
animais e caso sim, se esta se dá de forma positiva (do ponto de vista igualitário, biocêntrico) ou negativo (simplesmente lidando com os animais como entretenimento ou instrumentos oriundos de um pensamento antropocêntrico).

Sob a razão histórica (2) da perspectiva vigente, a concepção de mundo antropocêntrica em relação ao uso de animais é autorizada por teorias duvidosas. Segundo Salert e Fensterseifer (2007), "ao afirmar que os animais não possuem nenhuma razão e, portanto, tampouco valor intrínseco, Descartes abriu caminho para a separação entre ser humano e Natureza que até hoje marca a abordagem científica em quase todas as áreas do conhecimento, bem como para o processo de instrumentalização e apropriação da Natureza e dos recursos naturais, o que, em grande medida, tem nos conduzido ao atual estágio preocupante de degradação ambiental."

Em 1754, Jean Jacques Rousseau argumentou em seu "Discurso sobre a Origem e Fundamentos da Desigualdade Entre Homens" que os animais devem fazer parte da lei natural; não porque eles são racionais, mas porque são seres sencientes. Mas a ciência é hegemônica e cheia de paradigmas, e assim a história da utilização de animais pela ciência foi sendo traçada. "Inspirado nesse princípio mecanicista adotado como modelo da ciência de então, o fisiologista Claude Bernard passou a difundir no meio acadêmico a insensível prática da vivissecção " (LEVAI, 2001).

Cabe ressaltar que o entendimento de Claude Bernard (1813-1878) em relação aos animais era assim como o de Descartes, funcionalista. Ainda no século XVIII "o filósofo Jeremy Bentham (1748-1832) argumenta que a dor animal é tão real e moralmente relevante como a dor humana e profetiza que: 'talvez chegue o dia em que o restante da criação animal venha a adquirir os direitos dos quais jamais poderiam ter sido privados, a não ser pela mão da tirania. Bentham alega ainda que o que deve ser mensurado é a capacidade de sofrer e não a de raciocinar, pois se a habilidade da razão fosse critério, muitos seres humanos, tais como bebês e portadores de deficiências especiais, também teriam que ser tratados como coisas. A partir dessas alegações, escreveu seu mais famoso trecho sobre o assunto. A questão não é: eles pensam? Eles falam? Mas: eles sofrem?" (DOVAL, 2008). Em 1892, Henry Salt publicou o livro "Animal's Rights: Considered in Relation to Social Progress". 0 inglês atuou como reformista na área prisionária, escolar, instituições econômicas e no tratamento animal. Foi ele quem apresentou a Gandhi às ideias de desobediência civil e não-cooperação através do livro de Henry Throeau "Civil disobedience", publicado em 1849. 
Já no século XX, Richard Ryder, psicólogo britânico que havia trabalhado em laboratórios de pesquisas em animais, em 1969, começou a militar contra as experimentações em animais, e se tornou um dos pioneiros do movimento de libertação animal (animal liberation). Foi em 1970 que Ryder (1975, 2001, 2015) utilizou pela primeira vez o termo especismo. É autor de alguns livros importantes para a causa: Victims of Sciente (1975), Painism: A Modern Morality (2001) e Putting Morality Back into Politics (2015).

E por último, sob o aspecto da razão social (3), destaca-se o papel da escola neste processo que influencia a formação dos sujeitos em sua relação cotidiana para com o seu ambiente. Problematizar alguns aspectos da Ética Contemporânea, da Bioética e da Educação Ambiental perpassa toda esta perspectiva antropocêntrica e dominadora do ambiente, que é o objeto de estudo deste trabalho: o paradigma antropocêntrico. A vigente e majoritária concepção de mundo manifesta este paradigma em nossa sociedade sob diferentes práticas cotidianas e também em argumentos que legitimam práticas utilitaristas.

Conforme entende Boff (2009, p.61), "Ter esquecido nossa união com a Terra foi o equívoco do racionalismo e do reducionismo científico em todas as suas formas de expressão. Ele gerou a ruptura com a Mãe. Deu origem ao antropocentrismo, na ilusão de que, pelo fato de pensarmos a Terra e podermos intervir em seus ciclos, podemos nos colocar sobre ela para dominá-la e para dispor dela a nosso bel-prazer". Sobre a relação de especismo, Bachinski (2009, p.11) constata o emprego de tal termo sendo utilizado "para caracterizar o preconceito baseado em aparências do ser humano para com outras espécies. Tratar mulheres injustamente apenas por serem mulheres é machismo, explorar pessoas negras apenas por que elas são negras, racismo. Especismo é um preconceito semelhante a esses últimos, quando desconsideramos seres de outra espécie biológica apenas por que eles não são da nossa espécie." Para Naconecy (2006):

\footnotetext{
Na prática, isso ocorre quando se abraça um preconceito contra animais só porque são animais. O especismo é uma forma de chauvinismo por que consiste no tratamento inferior, discriminatório e diferenciado por parte dos membros de uma classe privilegiada (a 'superior') daqueles indivíduos que estão fora dessa classe, e para o qual não há uma boa justificativa. De fato, o especismo poderia ser visto como eticamente pior que o racismo e o sexismo, porque os animais são menos capazes de se defender e os mais facilmente vitimizados, se comparados com a situação dos seres humanos oprimidos. Como todo chauvinista, o especista pensa que os animais só têm valor ou nos impõem obrigações éticas na medida que eles atendem nossos interesses, propósitos, necessidades e preferências (NACONECY, 2006, p. 69-70).
} 
O que está em jogo, de acordo com Nussbaum (2001) é "uma das questões morais mais cruciais de nosso tempo". De acordo com Bartlett (2007):

\begin{abstract}
Em algumas ocasiões, os tribunais têm admitido explicitamente o especial valor de um animal de companhia em relação ao seu proprietário, mas, ao assim procederem, seguem o padrão de se estabelecer valores em termos antropocêntricos. Raramente o Poder Judiciário considera os animais nãohumanos como fins em si mesmos, seres que possuem interesses próprios. Quando o foco do debate se desvia para esta direção, tem-se discutido a tentativa de situar o status legal de animais não-humanos em algum lugar entre a propriedade e as pessoas. (...) Neste contexto, a questão jurídica central é atualmente resumida da seguinte maneira: 'Animais não são humanos e não são objetos inanimados. No entanto, até o momento, o Direito possui apenas duas categorias claramente separadas para lidar com essa distinção: propriedade ou pessoas" (BARTLETT, 2007).
\end{abstract}

Os parâmetros observados nas ações de responsabilidade civil costumam se basear não sobre a perda do animal não-humano em si considerada, mas sobre o sofrimento humano que essa perda do animal provoca. Nestes casos, os autores geralmente obtinham indenizações baseadas no dano moral representado pela perda do animal de estimação, ainda que tal pagamento ocorresse dentro do parâmetro da morte do animal encarado como perda da propriedade. Nestes julgados, 'a reparação é estabelecida com base na reação do proprietário ao sofrimento do animal' (NACONECY, 2006).

Ainda sobre o entendimento de um Argumento Ecológico, Naconecy discursa que:

do mesmo modo que nos serviríamos de uma sólida argumentação moral para justificar a luta para reduzir/eliminar os efeitos da nossa hipotética má sorte cósmica (da casualidade que, do ponto de vista humano, nos desfavoreceria frente a outros seres), também a má sorte real que os animais tiveram não deve ser deixada sem um controle ético: 'Poderíamos ser nós [grifo do autor] a ocupar seu lugar nas jaulas ou nas mesas de vivissecção, e é uma verdade incontroversa que não gostaríamos disso nem um pouco. Ou seja, a moral deve ser ditada pela boa ou a má sorte' (NACONECY, 2006, p.100).

\title{
MATERIAIS E MÉTODOS
}

Conhecendo a origem da palavra Pedagogia (do grego: "paidós" - criança; "agogé"condução), entende-se a importância de analisar como a pedagogia conduz os seus “clientes" (FREIRE, 2002). Assim, levantamento de material para a pesquisa se deu em três momentos: 1) conhecendo o campo de estudo; 2) observação-participante; 3) atividade de livre associação. Estas etapas de pesquisa estão descritas na metodologia. Eis o motivo de 
analisarmos uma escola de abordagem diferente da tradicional: conhecer como outros modelos lidam com o paradigma antropocêntrico. Analisaremos agora a metodologia utilizada e os resultados advindos das três etapas de pesquisa.

Conforme Reigota (1991) é necessário conhecer as concepções das pessoas envolvidas sobre meio ambiente, pois, só assim será possível realizar atividades. Quadro 01: Tipologia das concepções de meio ambiente segundo Reigota (1991), uma perspectiva que norteará as análises da atividade proposta.

Quadro 1 - Tipologia das concepções de meio ambiente segundo Reigota (1991)

\begin{tabular}{|l|l|}
\hline CATEGORIAS & CARACTERÍSTICAS \\
\hline Naturalista & $\begin{array}{l}\text { Meio ambiente como sinônimo de natureza } \\
\text { intocada evidencia-se somente os aspectos } \\
\text { naturais; }\end{array}$ \\
\hline Antropocêntrica & $\begin{array}{l}\text { Evidencia a utilidade dos recursos naturais para } \\
\text { a sobrevivência do ser humano; }\end{array}$ \\
\hline Globalizante & Relações recíprocas entre natureza e sociedade. \\
\hline
\end{tabular}

Fonte: Reigota, 1991.

E ainda apara ampliar os entendimentos sobre as diferentes concepções de mundo, é necessário destacar Gauthier (2009) quando a partir da leitura em francês de Descola (2005) sintetiza e explicita as concepções conforme a forma de se praticar o pensamento nas culturas hoje conhecidas da Terra. Segundo estas referências, as concepções podem ser divididas em quatro:

a - O pensamento "animista", onde, para os seres humanos, muitos seres não humanos, animais, plantas, pedras etc., também, pensam e possuem intenções e até, uma cultura própria (...) Todos os seres têm um espírito e uma cultura, mas diferenciam-se pela aparência corporal, natural. b - 0 pensamento "totêmico", onde cada clã tem uma planta ou um animal como origem, herói fundador. (...) homens e não-homens são os efeitos dos percursos das criaturas do sonho, - os ancestrais comuns -, e as sementes dessas criaturas moram nos seres existentes, humanos e não humanos, criando múltiplos laços transversais. O casamento ou união entre clãs é o momento de equilíbrio entre esses laços. No caso, a natureza é relativa e a cultura igualmente. A diferença é onipresente. c - $\mathbf{O}$ pensamento “analógico", encontrado no candomblé afro-brasileiro, em grandes civilizações das montanhas das Américas central e do sul, assim como na Índia, na China ou na Europa da Idade Média e da Renascença. Aqui tudo é universal, a cultura como a natureza: o mundo é caracterizado por uma proliferação de singularidades e de polissemias que se combinam numa ordem única. Uma entidade espiritual é relacionada a um lugar, uma cor, uma qualidade psicológica ou física, um ser da natureza etc. Existem analogias que se dividem e refletem infinitamente, sendo 
Deus, ou o Tao, ou então o Inca, o princípio inatingível de unificação. d - o pensamento eurodescendente, ou "naturalismo" - já que se caracteriza pela crença na universalidade da experiência que temos da natureza, concebida como independente das culturas e cujas leis podem ser conhecidas a partir de dispositivos científicos. Neste caso, a natureza é pensada como universal (a mesma, com as mesmas leis, para todos) e as culturas (DESCOLA, 2005 apud GAUTHIER. 2009).

Conforme o entendimento das referências supracitadas destaca-se que:

- o pensamento naturalista remete à universalidade e evidencia os aspectos de uma natureza intocada;

- o pensamento biocêntrico tem como foco a vida, assim como o ecocêntrico o ambiente (ecossistema) e o cosmocêntrico partidário da Teoria de Gaia (LOVELOCKE, 1989);

- o pensamento antropocêntrico é caracterizado pelo foco no homem e por um pensamento de utilitarismo para com o ambiente e os animais - vale pontuar que, segundo Rachels (2006), utilitarismo é uma teoria ética (...) que sustenta que os atos certos são aqueles que produzem a maior quantidade de felicidade para a maior quantidade de pessoas afetadas;

- o posicionamento de distanciamento do homem da sociedade é caracterizado pela descontextualização com o ambiente e;

- o pensamento contextualizado ou globalizante (re)insere o homem na natureza, o que reflete numa visão de sociedade mais harmônica que a antropocêntrica. $O$ material analisado foi interpretado sob esta ótica e obtido a partir das etapas de pesquisa, as quais foram propostas pela metodologia descrita a seguir.

Entendendo o contexto da escola, que foca o ensino no desenvolvimento das particularidades dos educandos, optamos pela escolha da pesquisa qualitativa, visto que:

A investigação quantitativa atua em níveis de realidade na qual os dados se apresentam aos sentidos e tem como campo de práticas e objetivos trazer à luz fenômenos, indicadores e tendências observáveis. A investigação qualitativa trabalha com valores, crenças, hábitos, atitudes, representações, opiniões e adequa-se a aprofundar a complexidade de fatos e processos particulares e específicos a indivíduos e grupos. A abordagem qualitativa é empregada, portanto, para a compreensão de fenômenos caracterizados por um alto grau de complexidade interna" (BALBI, 1999, p.1). 
As primeiras investigações para o desenvolvimento da pesquisa caracterizaram o reconhecimento do campo de estudo. Essas investigações foram possíveis graças à realização de entrevistas com coordenadores pedagógicos, professores de biologia e diretora da escola. Ainda no âmbito do reconhecimento do campo de estudo, fez-se o uso da metodologia da observação-participante para conhecer as práticas docentes, os perfis de cada turma e os temas abordados em sala de aula na época da realização desta pesquisa. Após a observação-participante, o observador propôs a mesma atividade para três turmas a fim de analisar as contextualizações dos temas ser humano/ natureza/ outros animais. Esta atividade foi caracterizada pela utilização da metodologia brainstorm, e posterior associação das palavras expostas em um diagrama de Venn (TRIVIÑOS, 1987).

Dentre as etapas da pesquisa os termos utilizados para designar a pesquisa qualitativa, optaremos pela utilização de, além do reconhecimento do campo de estudo, duas outras metodologias qualitativas: observação participante e grupo focal. Além dessas primeiras investigações, após a análise dos dados, será reagrupado o grupo focal para uma discussão após a apresentação dos dados, caracterizando a aplicação de uma triangulação analítica, com o objetivo de complementar os dados com as observações dos participantes do grupo focal (TRIVIÑOS, 1987).

\section{Considerações éticas}

Essa pesquisa se propõe a fazer uma análise social da transmissão do ensinamento dos professores para os alunos. Como essa pesquisa se baseia na observação dos estudantes e professores e também a comunicação com os professores através de um grupo focal, utilizou-se como ferramenta de esclarecimento sobre a pesquisa e de registro de voluntariedade o termo de consentimento livre e esclarecido (Anexo I: Termo de consentimento livre e esclarecido destinado ao grupo focal). Nesse termo está descrito que a participação na pesquisa é voluntária e o entrevistado poderá se ausentar da entrevista ou da participação em qualquer momento, não sendo obrigado a responder qualquer pergunta.

Além disso, para a observação dos alunos e professores no campo de estudo, será solicitada, após o esclarecimento da pesquisa ao diretor e ao coordenador pedagógico, a autorização ao desenvolvimento do trabalho. O sigilo absoluto dos participantes será mantido. O termo de consentimento livre e esclarecido para a observação participante, 
destinada ao diretor e ao coordenador pedagógico, específico para observação, está presente no Anexo II.

\section{Reconhecimento do campo de estudo}

O reconhecimento do campo de estudo é a primeira etapa da pesquisa, visando construir com o diretor da escola e com o coordenador pedagógico as melhores estratégias para o estudo de observação participante. Assim, esse primeiro contato gerará diretrizes para o prosseguimento da pesquisa. 0 estudo se baseia na análise do sistema pedagógico em relação à transmissão do conhecimento e do posicionamento sobre os animais, então para a etapa de reconhecimento, o objetivo será identificar quais são as disciplinas que melhores, mais amplamente e profundamente abordam o assunto, possibilitando uma coleta de dados e impressões mais extensa.

Neste dado momento da pesquisa, buscaremos conhecer a realidade da escola, como ela trabalha as questões ambientais, e perguntar se há ensino sobre direitos animais e de que forma este se dá. Estas observações guiarão as próximas etapas da pesquisa.

\section{Observação-participante}

A observação será guiada pelas informações coletadas na etapa anterior. Sendo a turma observada e os critérios de seleção desenvolvidos em colaboração com os responsáveis pela didática escolar. 0 assunto central da pesquisa é de que forma o cotidiano escolar e os professores manifestam suas concepções de mundo sobre a inserção do homem no ambiente e da relação deste com os animais sendo os indicadores escolhidos para análise desse assunto a obtenção de informações as práticas de sala de aula, a contextualização dos temas abordados a partir da exposição sistêmica e a análise do Projeto Político Pedagógico.

Repensar 'questões ambientais' ou 'educação ambiental' é algo muito mais complexo do que simples técnicas ou 'tecnologias limpas' de resolução de problemas. Estudar, abordar, fazer a gestão de questões ambientais implica considerar a inerência das dimensões físicas, sociais, culturais, econômicas, tecnológicas, religiosas e históricas do fenômeno/questão na qual se debruça a atenção (BARBOSA, 2002). 
Se o trabalho com valores tem sido atualmente indispensável na educação escolar como um todo, a sua necessidade se torna indiscutível ao lidarmos com certas temáticas, como a ambiental (BONOTTO e SEMPREBONE, 2010). O avanço para o pensamento de sociedade sustentável advém, como entende Jacobi (2003), de uma transformação institucional. Sendo esta instituição a Escola, observaremos a dimensão valorativa da educação ambiental, ao se propor a construção de novas formas de relação sociedadenatureza (LOUREIRO, 2000).

\section{Atividade em sala de aula}

Em busca de conhecer de como as subjetividades dos educandos lidam com os temas escolhidos (ser humano, natureza e outros animais), foi elaborada uma atividade a fim de evidenciar quais são os posicionamentos destes sujeitos e quais concepções de mundo os conduz. $O$ entendimento das particularidades dos alunos se deu pela soma das análises do cotidiano da escola, da observação-participante e de uma atividade de associação. As associações configuraram essa etapa de pesquisa quando, através de um brainstorm, os alunos escolheram palavras para representar seus pontos de vista sobre ser humano, natureza e outros animais. Após a exposição das palavras as mesmas foram agrupadas pelos alunos no Diagrama de Venn (Anexo III: Atividade de associação (Diagrama de Venn) a fim de mostrar com quais temas as palavras escolhidas melhor se relacionam.

Deu-se início às reflexões sobre o tema, e no quadro, foi demonstrado se as palavras para os alunos e para turma seriam harmônicas/positivas, desarmônicas/negativas ou neutras. Essas reflexões, em cada turma, promoveram um debate diferenciado acerca de temas que caracterizariam as turmas em questão. O debate acerca da visão de dominação e de falas simplesmente utilitárias prosseguiu com o auxílio do texto "Da utilidade dos animais" de autoria de Carlos Drummond de Andrade (Anexo IV: Da utilidade dos animais). Por último, a fim de ordenar e significar a contextualização individual, foi pedido aos alunos que, escrevessem uma frase no verso da folha entregue a resposta para a pergunta: "para você, como se relacionam o ser humano, natureza e os outros animais? ", e ainda, caso desejável, que promovessem a reorganização das palavras no diagrama.

A escola sócio-construtivista trabalha com as particularidades dos educandos e para a autonomia por parte docente, a atividade foi caracterizada por seu perfil de propriedade 
do pesquisador deste trabalho, o que facilitou as análises e a execução da atividade. Como diria Paulo Freire (2002), o ensino dos conteúdos, criticamente realizado, envolve a abertura total do professor ou da professora, à tentativa legítima do educando para tomar em suas mãos a responsabilidade de sujeito que conhece.

A fim de testar a metodologia, a atividade foi aplicada na turma do sexto ano, lapidada e aplicado ao sétimo ano do ensino fundamental e também ao terceiro ano do ensino médio. 0 sexto e sétimo ano foram escolhidos devido aos atuais temas lecionados serem relacionados com a parte ambiental. Já o terceiro ano foi escolhido, por ser uma série que já teve aulas de praticamente de todo o conteúdo e por, provavelmente, possuir maior facilidade ao fazer conexões sistêmicas de acordo com o planejamento curricular orientado pelos parâmetros curriculares nacionais.

\section{Avaliação da atividade realizada}

A análise dos materiais obtidos foi proporcionada devido ao contato com os alunos durante a vivência na escola, possibilitando em linhas gerais o observador conhecer um pouco mais esse público-alvo. Ao analisar as associações foram consideradas as falas dos alunos durante a atividade atrelando à formação que estes tiveram, seja através da Pedagogia Waldorf, do sócio-construtivismo ou educação inclusiva. Tecendo essa rede de análise, as associações foram interpretadas segundo os seguintes indicadores de análise que sugerem:

a) relação de dominação - concepção que demonstra a dominação desarmônica do homem para com a natureza e os animais;

b) relação de equidade - coloca os seres vivos num mesmo patamar;

c) influência de fatores midiáticos - respostas diretamente influenciadas por campanhas da mídia que trabalham a questão ambiental de forma rasa;

d) visão fragmentada de ambiente - concepção bastante influenciada pelos fatores midiáticos e trabalha a questão ambiental de forma rasa; 
e) hierarquização das espécies - concepção baseada em fatores como a inteligência do ser humano para legitimar sua superioridade perante as outras espécies e a exploração/dominação;

f) antropomorfização do ambiente - coloca o homem deus de todas as coisas;

g) distância do homem do ambiente - concepção que materializa o discurso que "o meio ambiente é tudo que nos cerca" ao não relacionar o homem à natureza;

h) aproxima o homem ao ambiente - relaciona o homem com a natureza ou com os animais;

i) visão utilitária da natureza e dos animais - difere de utilitarismo, e só há valoração das espécies e do ambiente pela utilidade que os mesmos possam vir a ter para a espécie humana.

A associação de cada aluno foi interpretada individualmente, e partir das valorações individuais e buscou-se entender o que para cada aluno seria positivo/harmônico, negativo/desarmônico e neutro perante as relações do homem/natureza, homem/animais, natureza/animais e homem/natureza/animais. De acordo com o entendimento dos indicadores postulados acima, as respostas de cada aluno foram organizadas (Quadro 02) .

Quadro 2 - Tabela de organização das respostas para a atividade de associação

\begin{tabular}{|c|c|l|l|l|}
\cline { 2 - 5 } \multicolumn{1}{c|}{} & \multicolumn{3}{c|}{ Indicadores } \\
\cline { 2 - 5 } \multicolumn{1}{c|}{ Temas } & Classificação & Harmônico & Desarmônico & Neutro \\
\cline { 2 - 5 } & Homem & & & \\
\cline { 2 - 5 } & Animal & & & \\
\cline { 2 - 5 } & Natureza & & & \\
\cline { 2 - 5 } & Homem/Natureza & & & \\
\cline { 2 - 5 } & Homem/Animal & & & \\
\cline { 2 - 5 } & Animal/Natureza & & & \\
\cline { 2 - 5 } & Homem/Animal/Natureza & & & \\
\end{tabular}

Fonte: Própria.

Cabe ressaltar que não foram realizados perfis quantitativos para a análise, pois buscamos entender a individualidades e não as generalidades. A fim de investigar esta relação ser humano / natureza / outros animais/ natureza nos educandos desta instituição, foi realizado, primeiramente um estudo sobre esta pedagogia. Para Bignozzi e Barros (2007) 
a pedagogia Waldorf:

Está fundamentada numa ciência empírica que surge de uma visão antropológica: a Antroposofia ou Ciência Espiritual. Esta acrescenta base espiritual para a educação. Segundo a Antroposofia, o ser humano possui quatro corpos que o formam e constituem, cada um com suas funções. O corpo físico com a função estrutural; o corpo etérico com a função de manter a vida; o corpo astral cuja função é proporcionar sentimentos e sensações; o - eu-humano que permite o homem pensar, é a sua alma. A Pedagogia Waldorf leva em consideração as fases evolutivas do homem, juntamente com a evolução destes elementos através dos setênios (períodos de sete anos) e para tanto, é formada por matérias que desenvolvem conhecimentos cognitivos, biológico-tecnológicos e prático-artísticos. O professor acompanha seus alunos desde a $1^{\text {a }}$ até $8^{\text {a }}$ série, para que haja intimidade. Tais conhecimentos se dão através da atenção voltada para o mesmo assunto dentro das diversas disciplinas. (...) É importante ressaltar que a Pedagogia Waldorf busca uma educação mais humanizada e harmônica através do desenvolvimento das potencialidades dos educandos. Além disso, é uma metodologia que possui o olhar voltado ao íntimo do ser humano e, com isso, observa aspectos de sua constituição que não são levados em consideração em outras abordagens. (BIGNOZZI e BARROS, 2007, p. 599 e 600).

A Pedagogia Waldorf, possui apenas um professor que leciona todas as matérias, e para tal este deve ter uma formação específica que duração de quatro anos, sendo os dois primeiros gerais e os dois últimos específicos para a formação de coordenadores, professores do primeiro/segundo/terceiro setênio, entre outros. A escola em questão adota esta pedagogia apenas para a Educação Infantil, e está em transição para a aplicação da Pedagogia Waldorf no primeiro segmento do Ensino Fundamental (até o quinto ano). Entretanto, a observação-participante não foi possível para as séries citadas visto que, a abordagem Waldorf não trabalha os conteúdos em disciplinas separadas, nem faz uso do livro didático, o que dificultou complicou o planejamento para a pesquisa deste trabalho no Ensino Waldorf, pois a professora estava lecionando na época conteúdos referente à matemática, e não tinha previsão para abordagem assuntos referentes às ciências naturais para a Educação Infantil., o Assim, a pesquisa foi conduzida que conduziu a pesquisa a outro público-alvo ao Ensino Sócio-construtivista. As turmas analisadas pertenciam a faixa de $6^{-}$ ao $9^{\circ}$ ano do Ensino Fundamental, Ensino Fundamental II, e do $1^{\circ}$ ao $3^{\circ}$ ano do ensino médio., os alunos do terceiro ano do ensino médio desta escola sócio-construtivista. Antes de chegar à esta turma, foram realizadas outras atividades que seguem abaixo descritas.

\section{RESULTADOS E DISCUSSÃo}

No primeiro momento, foram realizadas entrevistas com os professores de biologia 
que dão aula para o Ensino Fundamental II e Ensino Médio, coordenadores da escola e diretora da escola. Analisamos ainda o Projeto Político Pedagógico da Escola e o modelo de avaliação. Mediante a apresentação do pesquisador, deu-se início à pesquisa.

Segundo o portal eletrônico do colégio, a escola em sua filosofia, busca humanizar o humano no projeto de um educar onde as relações tanto intelectuais quanto as afetivas são preponderantes no desenvolvimento de uma sociedade com indivíduos que atuem de forma responsável e ética e que os valores humanos sejam pensados e repensados com criticidade. o corrente ano letivo conta com trinta professores (entre os quais cinco lecionam de acordo com a Pedagogia Waldorf) e cento e oitenta e um alunos. O espaço da escola em sua estrutura física é arejado e todos os brinquedos são confeccionados de madeira e materiais naturais/reciclados.

Durante as visitas à escola, ocorridas durante os meses de outubro e novembro, observou-se um alto número de alunos portadores de necessidades especiais. Essa observação foi confirmada pela diretora da escola. A escola faz um trabalho de inclusão recebendo estes alunos que outras escolas do município rejeitam, ainda, para a diretora, é necessário limitar o número de vagas por turma, pois não é interessante a realidade de uma turma com muitos alunos portadores de necessidades especiais nem para estes nem como para os ditos 'normais'. Em algumas turmas observadas, notou-se que esta realidade chega a ser quase cinquenta por cento da turma. Em entrevista, a diretora revelou que:

\footnotetext{
O diferencial muito forte em Nova Iguaçu, é o sucesso da gente ter conseguido fazer a inclusão... também tem os problemas, não vou negar, mas assim, praticamente nós ficamos conhecidos por fazer esse trabalho. (...) e a gente começou a ter muita procura, na realidade, o projeto é que cada turma tenha no máximo três alunos [especiais], porque o rico é você poder trazer essa criança pra uma realidade, dita aparentemente normal né? Onde possa haver o desenvolvimento das crianças, das atitudes (...) e aí a procura ficou muito grande, nós acabamos assim, em algum momento tendo que recusar [alguns alunos especiais] mas, com muita pena, muito pesar mesmo, porque os pais não conseguiam espaço em outra escola. Aí você vê essa realidade da gente ter um grupo considerável de crianças especiais (...) e também não é rico que você trabalhe com crianças só especiais, não é rico nem pra criança nem pro outro grupo (...) nós não podemos ficar mesmo com este perfil, por bem mesmo da comunidade escolar. $O$ rico é você ter a diversidade.
}

A avaliação dos alunos desta escola se dá através é feita por de um sistema de conceito e não de notas numéricas. A interpretação dos conceitos se dá através dos conteúdos conceituais, procedimentais e atitudinais. No caso dos alunos portadores de necessidades especiais avalia-se mais do que a capacidade de assimilação dos conteúdos, 
sendo tão importante quanto a postura em sala de aula, a atitude, o respeito e a sociabilidade. Os alunos com maior grau de dificuldade nestes aspectos de avaliação são acompanhados mais de perto por uma orientadora, e não ficam muito tempo em sala de aula, para estes, o professor elabora apenas um relatório a ser avaliado posteriormente. A diretora citou ainda, que entre os ex-alunos da escola portadores destas necessidades, muitos hoje trabalham com habilidades manuais.

Os professores de biologia foram entrevistados e observou-se uma distinção no que diz respeito à experiência em sala de aula e à abordagem sócio-construtivista. $O$ professor do ensino médio já trabalha há sete anos na escola, enquanto e a professora do ensino fundamental II começou este ano na escola está presente há menos de um ano. Foram observadas as aulas destes dois professores e realizado um diário de campo sob o prisma da metodologia da observação-participante, cujos resultados seguem descritos abaixo. Nesta etapa da pesquisa, observou-se durante o período da pesquisa as aulas de biologia do ensino fundamental II e ensino médio, ou seja, observou-se as aulas do sexto, sétimo, oitavo e nono ano do ensino fundamental II e do primeiro, segundo e terceiro ano do ensino médio. Primeiramente, chamou atenção o espaço da sala de aula, é bastante espaçado e as carteiras em geral são dispostas em dupla e fazendo formato de "U". Alguns alunos se movimentam durante as aulas, o que tem muita importância para principalmente aqueles alunos portadores de necessidades especiais e/ou aqueles com dificuldade de concentração. 0 espaço da sala de aula é adornado em suas paredes com os trabalhos executados pelos alunos, e nos fundos da sala, há armários para que os alunos guardem seus materiais mais pesados.

Os cartazes que ficam expostos nas paredes são produzidos durante as aulas. Estes cartazes são confeccionados de acordo com um levantamento de concepções sobre os temas específicos e pela medicalização do professor, que segue ajudando a decifrar e entender os conteúdos da biologia. A abordagem conteudista, entretanto, prossegue em sala de aula, enquanto, por exemplo os alunos do segundo ano do ensino médio estão aprendendo sistema epitelial, conjuntivo, nervoso, muscular... pouco ou /nada é contextualizado, através de uma visão integrada com o corpo e meio ambiente junto aos alunos sobre os temas em questão.

As outras turmas observadas obtiveram um resultado diferenciado no que diz respeito a esta interação: realidade e conteúdo. Destaca-se que para o oitavo ano, durante a 
aula de sistema urinário pontuou-se o tratamento da hemodiálise; o nono ano segue fazendo pesquisas a partir de temas escolhidos pelos alunos, e para o tema de saúde e nutrição relacionou o desperdício das cascas de alimentos ricos em nutrientes, e do aproveitamento destes pelos alimentos alternativos; o sexto ano segue aprendendo sobre Estrutura da Terra, e não foi observada contextualização não-teórica; o sétimo ano está significando as estruturas botânicas ao trazerem folhas de casa para identificar e conhecer sua morfologia e no primeiro ano está sendo abordado o corpo humano.

Segundo a professora de ciências a contextualização dos temas é algo que fica sobrecarregado ao professor de ciências, já que para isso ele faz uso dos temas transversais. Ao ensinar conteúdos celulares, a contextualização conteúdo - realidade, segundo a professora, é mais difícil. Para ela, os temas transversais poderiam ser abordados também em outras disciplinas e por fim, acredita que a abordagem sócio-construtivista acaba caindo na abordagem conteudista porque os pais cobrarão.

Sobre a importância da contextualização, Fonseca (2005) nos traz que as diversas formas de produção de conhecimento dependerão de seu contexto e das suas interconexões. De onde vem a célula? De que ela é composta? Como ela funciona? O que elas compõem? Que mecanismos executam? O que é vida? Quais as diferenças entre células vegetais e animais? Como utilizamos estes? Quais relações são benéficas e quais são maléficas? São estas, algumas interconexões e contextualizações prováveis para o tema celular. É necessário, porém pontuar que esta não é uma receita para contextualização de temas, e sim apenas reflexão com caráter de uma possibilidade. Além dessas contextualizações, o ensino da biologia celular integrado com outras disciplinas, ajudará na fixação do conhecimento e nas discussões entre os alunos, tornando o tema mais interessante. Integrar a biologia celular com a química (a importância da polaridade da água para a formação da vida e da formação de membranas lipídicas), com a física (investigando metodologias de estudo da biologia, microscopias, estudo dos corpos), com a literatura e línguas (com um olhar biológico sobre os temas trabalhados, bem como uma interação com as epidemias e a história na contextualização dos textos), integrar esses temas não apenas ajudará os alunos a entenderem e a fixarem temas, mas ajudará a eles a desenvolverem uma postura investigativa/ativa perante os problemas.

Durante a observação constatou-se que aulas do ensino fundamental II costumam ter dois momentos, a teoria e depois o uso de jogos a fim de verificar o entendimento dos 
conteúdos naqueles alunos que não se manifestam tanto durantes as aulas. Porém, observou-se uma competitividade por parte de alguns alunos em desarmonia à filosofia de humanização, visto que, nem todos jogos se manifestaram como cooperativos, e sim competitivos. Estes jogos, porém, reforçaram a integração dos conteúdos. Os temas ambientais aparentaram serem mais facilmente contextualizados que os conteúdos celulares. Essa constatação pode ser confirmada pelos resultados da etapa seguinte quando, muitos alunos observam que o homem tem o dever de preservar a natureza enquanto para os animais, as visões expostas sugerem apenas uma abordagem utilitária dos animais.

Durante essa etapa apareceram debates bastante diferenciados em cada turma, sendo esses respectivos aos perfis de cada de turma uma, o que só vem a confirmar a necessidade da autoria das atividades e aulas do professor para que ele possa lidar com total autoridade sobre a metodologia aplicada e esse imenso campo de possibilidades do cotidiano escolar interagindo os debates com as curiosidades, as realidades e os conhecimentos específicos. Nesse contexto, cabe antes de analisar as atividades e respostas de cada turma, citar Paulo Freire (2002):

\begin{abstract}
Percebe-se (...) a importância do papel do educador, o mérito da paz com que viva a certeza de que faz parte de sua tarefa docente não apenas ensinar os conteúdos, mas também ensinar a pensar certo. Aí a impossibilidade de vir tornar-se um professor crítico se, mecanicamente memorizador, é muito mais um repetidor cadenciado de frases e de idéias inertes do que um desafiador. 0 intelectual memorizador, que lê horas a fio, domesticando-se ao texto, temeroso de arriscarse, fala de suas leituras quase como se estivesse recitando-as de memória - não percebe, quando realmente existe, nenhuma relação entre o que leu e o que vem ocorrendo no país, na sua cidade, no seu bairro. Repete o lido com precisão, mas raramente ensaia algo pessoal. Fala bonito de dialética mas pensa mecanicistamente. Pensa errado. É como se os livros todos a cuja leitura dedica tempo parto nada devessem ter com realidade de seu mundo. A realidade com que eles têm que ver é a realidade idealizada de uma escola que vai virando cada vez mais um lado aí, desconectado do concreto. (FREIRE, 2002, p.14-15).
\end{abstract}

As reflexões proporcionadas pela atividade e pelos debates podem ter contribuído para um pensar mais crítico desses alunos, porém, observamos observou-se a necessidade de outros trabalhos para fazê-los repensar efetivamente sobre as relações sistêmicas e possivelmente, ampliar suas concepções. Nessa etapa, levantou-se uma hipótese à medida que foram aplicadas as atividades: a valoração à vida como fator principal de relacionamento a seres vivos e a natureza é oriunda da formação Waldorf? 


\section{Testando a metodologia: lidando com falhas e surpresas no sexto ano}

O sexto ano do ensino médio foi a turma escolhido a para o teste da metodologia. Primeiramente, explicou-se a atividade no quadro, fazendo uso de um exemplo fictício (Figura 1: Quadro explicativo da atividade de associação com exemplo fictício), o que foi construído segundo palavras dos alunos. Esta abordagem inicial, não se mostrou muito efetiva, justo que, muitos alunos foram influenciados pelas relações que os outros fizeram, portanto quando não sabiam, escolhiam um lugar e/ou uma palavra utilizada no exemplo. Desta forma, houve também uma variedade muito grande de palavras, o que dificultou a análise das relações que eles fizeram entre os temas expostas no quadro.

Figura 1. Quadro explicativo da atividade de associação com exemplo fictício

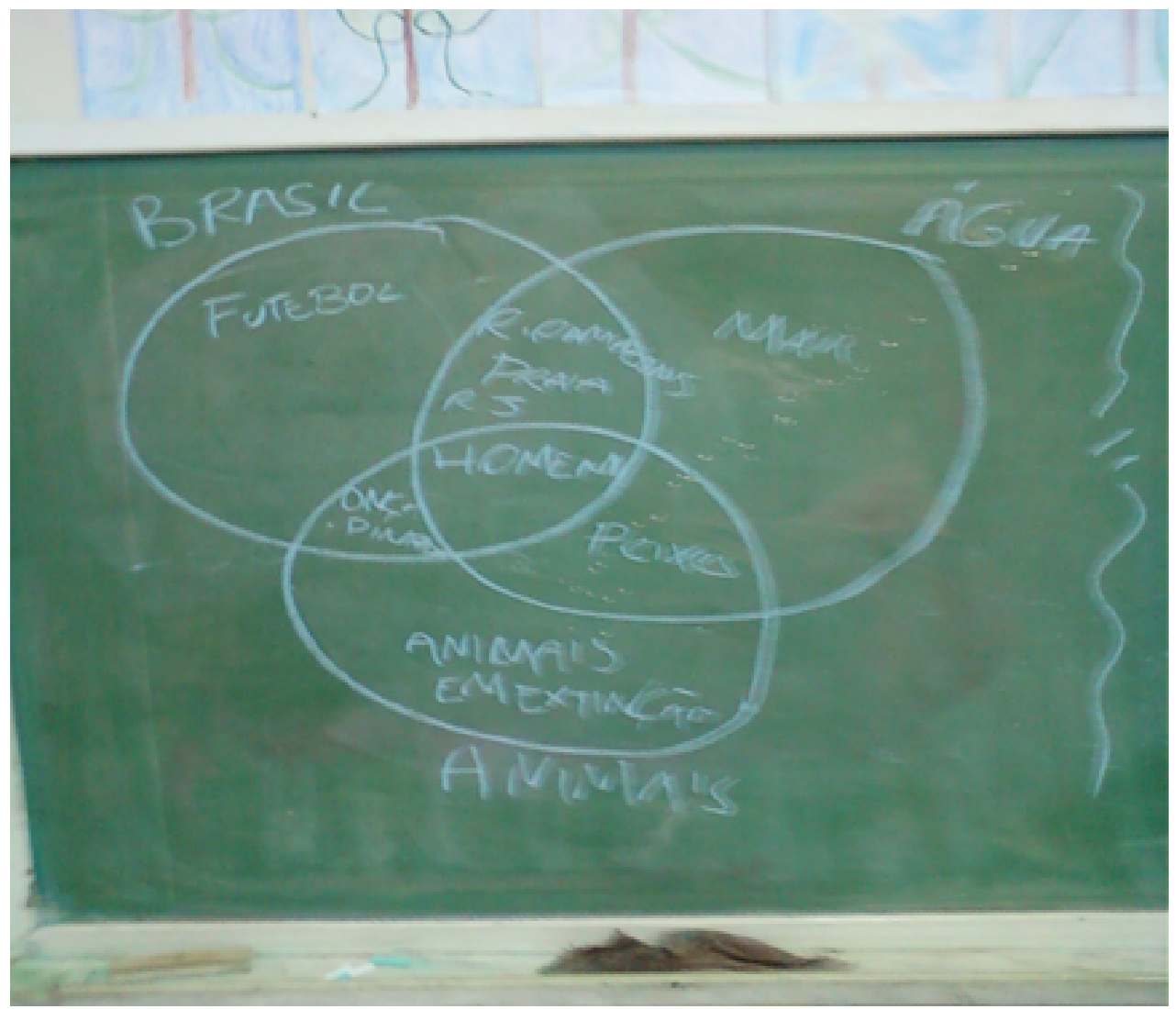

Fonte: Própria.

Não é possível também determinar se todos os alunos realmente compreenderam as intersecções do diagrama (para esta e para as outras turmas). Apesar de todas as turmas contarem com três ou quatro alunos portadores de necessidades especiais, apenas dois (no geral) não responderam efetivamente à atividade. Explicada a atividade, os alunos começaram a escrever. Observamos em suas respostas que palavras do quadro como "onça- 
pintada", "futebol" e "animais em extinção" foram comuns às respostas talvez por uma dificuldade metodológica, a qual foi modificada para a execução nas outras duas turmas escolhidas. Alguns alunos comentaram o que haviam escrito, e observou-se uma visão bastante influenciada pelos desenhos animados e filmes, quando um aluno ao relacionar os três temas colocou: "Tarzan e Jorge o rei da floresta"; outro aluno colocou "2012", outros dois alunos relacionaram o homem à "super-homem" e "cristo redentor".

Terminada a primeira etapa, lemos o texto de Drummond (1975), e para minha surpresa, enquanto lia-se a última frase três alunas falaram de cabeça a última frase da crônica: a professora de português trabalhara esse mesmo texto com a turma. Os alunos acharam bonito o texto. Devido a esta coincidência fez-se necessário entrevistar a professora de português, que segundo ela, passou esse texto, pois Drurmmond o tempo todo ironiza, e o que a motivou trabalhá-lo em sala foi mostrar que o professor é formador de opinião e que ele - o professor - não é perfeito. Segundo Cavalcante (2011):

A leitura é fundamental na aprendizagem. A leitura possibilita a ampliação de conhecimentos e a sua importância não se limita em decodificar mensagens, mas em estabelecer relações entre o texto e a leitura de mundo, entre o texto e a vivência. A leitura de mundo influencia na leitura do texto, assim como a leitura pode influenciar na leitura de mundo. Desta forma, ao exercitar a leitura de textos, exercita-se a leitura de mundo. (CAVALCANTE, 2011, p.70).

A segunda folha para possíveis alterações foi passada, e das mudanças que houveram, trocaram-se nomes de animais por outros ("arara-azul - onça-pintada" [aluno 2]; "onça-pintada - tigre" [aluno 7]; "lagarto - biguá" [aluno 8]) e outros as palavras da mesma família "sinônimos" ("futebol - voleibol" [aluno 7]; "racional - raciocínio" [aluno 8]), não havendo muitas alterações. Daqui em diante, foram analisadas apenas as primeiras folhas para todas as turmas, pois como a atividade não teve caráter de modificar as concepções de mundo esta segunda folha não se mostrou eficaz para a análise. As frases que eles escreveram ao término da atividade contribuíram bastante para significar as relações expostas.

Dentre as frases que relacionam os três temas de pesquisa, observou-se que os alunos dessa turma têm uma visão de equidade. Porém, cabe destacar a visão do aluno 3, que em sua frase diz que "O homem sofre com a natureza e mata os animais". Essa visão materializa um protecionismo à natureza e um descaso com os animais. A visão de preservação é bastante divulgada por campanhas da mídia, mas de forma rasa influencia bastante as crianças. A visão que se manifestou em geral foi relacionada à preservação da natureza, porém quanto 
aos animais a preservação só se materializou para o caso dos animais em extinção, o que também pode ser analisado como reflexo de campanhas de preservação de espécies ameaçadas de extinção. O aluno 7, diz que o principal relacionamento do homem/natureza/animais é cuidar do planeta, mais uma vez demonstrando a relação de equidade, pois para ele cuidar do planeta se relaciona aos três fatores. Ainda, cabe citar o quadro de análise de indicadores do aluno 5 (Quadro 03), que tem essa visão de valoração à vida ainda que o aluno relacione o fator extinção.

Quadro 3 - Tabela de respostas organizadas do aluno 05

\begin{tabular}{|c|l|l|l|l|}
\cline { 2 - 4 } \multicolumn{1}{c|}{} & \multicolumn{1}{c|}{ Indicadores } \\
\cline { 2 - 5 } \multicolumn{1}{c|}{ Classificação } & Harmônico & Desarmônico & Neutro \\
\hline \multirow{5}{*}{ Temas } & inteligente & \\
\cline { 2 - 5 } & Animal & & extinção & \\
\cline { 2 - 5 } & Natureza & & Não ce dão bem & \\
\cline { 2 - 5 } & Homem/Natureza & Depende um do outro & & \\
\cline { 2 - 5 } & Homem/Animal & Estão junto todo dia & & \\
\cline { 2 - 5 } & Animal/Natureza & Tem em todo lugar & & \\
\cline { 2 - 5 } & Homem/Animal/Natureza & & & \\
\hline
\end{tabular}

Fonte: Própria.

A palavra inteligente é um fator que hierarquiza, e foi encarado por este motivo como fator negativo/desarmônico, pois ele de certa forma é a justificativa para a relação de dominação do homem para com a natureza e com os animais, configurando, portanto, a exploração demasiada e o desequilíbrio. Outra palavra que legitima essa relação é "racional", materializada no quadro organizado do aluno 8 (Quadro 4.). Esse aluno diz que: "O homem deve preservar o animais e natureza. Porque eles são vida desse planeta". Representando assim uma visão teleológica e utilitária. Esse aluno hierarquiza os seres a partir de uma característica (raciocínio), sobre animais, apenas lhe é recordado aqueles pensa nos que estão em extinção e ainda nos animais domésticos, na relação homem/animal., não havendo relação/importância os outros animais.

Quadro 4 - Tabela de respostas organizadas do aluno 08

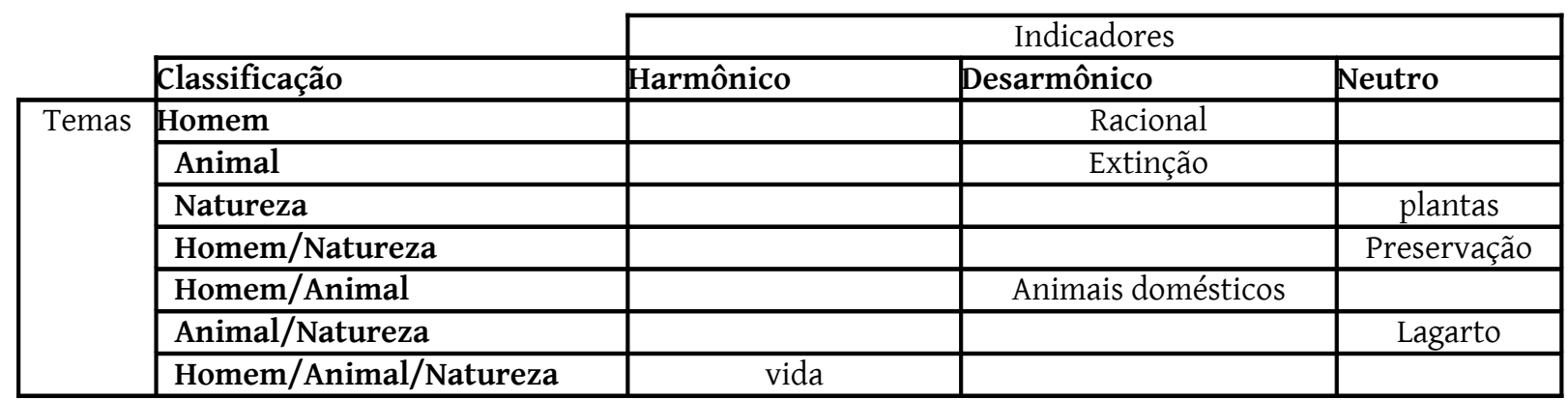

Fonte: Própria. 
Quanto a visão utilitária, cabe destacar além da frase do aluno 8, a do aluno 2: “A natureza é ótima, mas homem não cuida do que tem e acaba matando os animais e um dia vamos ficar sem.". Dentro desta visão destaca-se que as coisas têm valor devido à sua funcionalidade e não por outras razões, sejam de ordem ética, moral, ecológica, ambiental, religiosa, protecionista, etc. Chama atenção ainda, a colocação do aluno 1, que coloca como principal fator de relação entre homem - animal a "vontade própria", porém segundo ele, "o homem ele corta as arvores e destrói a natureza e maltrata os animais e não liga pro planeta".

\section{O sétimo ano e o debate vegetariano}

Eram catorze alunos em sala, e deu-se início à atividade. Mas desta vez seria um pouco diferente da realizada com o sexto ano: foi realizado anteriormente à atividade de associação um brainstorm relacionado às palavras escritas no quadro: homem, natureza, animais. Optou-se também não realizar o exemplo no quadro para não induzir associações. Foi realizado o brainstorm. Daí veio o impasse vegetariano. Logo de início, um aluno disse que era errado comer os animais - ele era vegetariano - daí outros alunos discordaram, e aconteceu um debate com foco na caça desenfreada, tendo a palavra "caça" sido colocada no quadro e influenciado no debate. Após o brainstorm, ocorreu a leitura do texto e o debate prosseguiu. Para entender melhor as visões dos alunos, ao lado de cada palavra a turma escolheu um sinal para saber se aquela palavra seria um fator negativo, positivo ou indiferente (Figura 2: Quadro com brainstorm realizado no sétimo ano). Adotamos ainda outro sinal que foi aplicado tanto para as palavras "caça", "criacionismo" e "evolucionismo" a fim de respeitar os diferentes tipos de visões ideológicas, religiosas ou científicas sem que fossem suprimidas convicções pessoais.

A observação de como se materializam as concepções das relações para com os animais e o ambiente na visão de um vegetariano, costumam ser muito mais críticas, mesmo porque, a relação de um vegetariano tende a ser mais harmônica com o ser humano, ambiente e animais. Porém, é necessário destacar que não há intenção em discutir nesse momento práticas de vegetarianismo. O debate quanto ao vegetarianismo voltou após a leitura do texto e, a turma concordou no aspecto da caça predatória ser um fator negativo, mas não sobre o vegetarianismo. 
Figura 2. Quadro com brainstorm realizado no sétimo ano

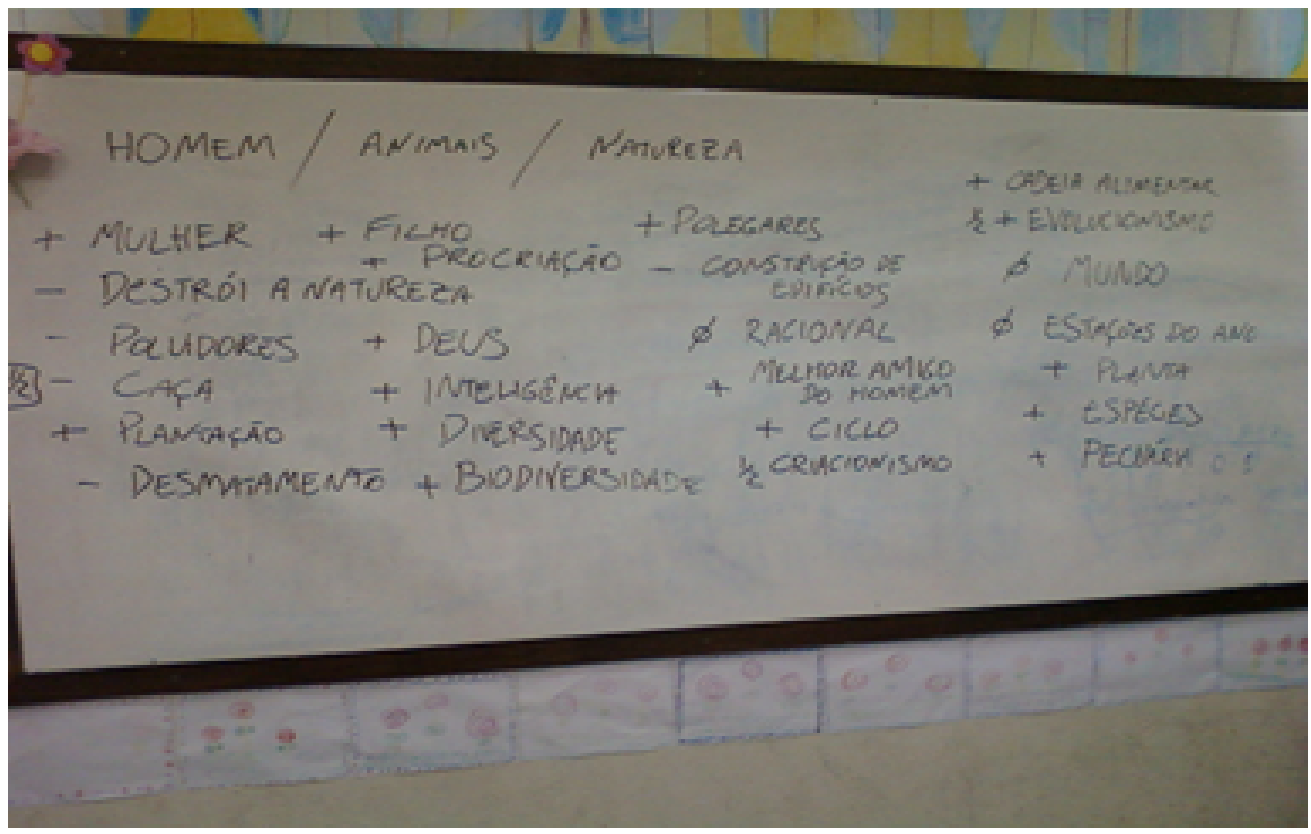

Fonte: Própria.

Conforme mostra a Figura 2, as relações harmônicas ou positivas para estes alunos são: mulher, plantação, filho, procriação, deus, inteligência, diversidade, biodiversidade, polegares, melhor amigo do homem, ciclo, planta, espécies e, pecuária; as desarmônicas ou negativas são: destrói a natureza, poluidores, desmatamento, e construção de edifícios; as indiferentes são: racional, mundo e, estações do ano; e as que são tanto quanto positivas e negativas são: caça, criacionismo e evolucionismo.

Nas associações percebemos muitas associações à caça e à cadeia alimentar devido ao debate que acabou por introduzir a atividade. Devido outra característica do perfil da turma (só ter duas meninas), a relação homem - mulher - filho - procriação foi muito abordada, e considerada como neutra para a análise, já que é um perfil exclusivo dessa turma. Porém, novamente a valoração da vida chamou atenção como característica comum. O aluno 11 manifesta em sua fala a visão de coabitação: "Homens, animais e natureza, os elementos primordiais e principais caracterizar o mundo"; o aluno 12 é mais pessimista "Para mim o que tem a ver com: homem/ animais/natureza é que o homem destruindo a natureza para construir moradias isso mata alguns animais e ficam sem aonde morar", mas tem a noção da interdependência que caracteriza suas relações. No quadro 05, pode-se observar suas respostas organizadas.

Este aluno apesar de enumerar vários animais, demonstrando a diversidade mostra um lado negativo ao associar a palavra "perigo" a animais. Sobre essa associação de perigo 
não há como inferir se é algo referente a alguma influência da mídia ou mesmo algum trauma que ele teve ou outra relação. Sua associação demonstra que a principal relação homem - natureza - animais é a destruição dos outros seres que não o homem. E há muitas características que indicam fatores negativos, entre os quais se destaca "matar animais para fazer casacos, bolsas, etc."

Quadro 5 - Tabela de respostas organizadas do aluno 12

\begin{tabular}{|c|c|c|c|c|}
\hline & & \multicolumn{3}{|c|}{ Indicadores } \\
\hline & Classificação & Harmônico & Desarmônico & Neutro \\
\hline \multirow[t]{7}{*}{ Temas } & Homem & & $\begin{array}{c}\text { Construção de edifícios; } \\
\text { poluidores; caça; destrói a } \\
\text { natureza; inteligência; } \\
\text { mundo }\end{array}$ & \\
\hline & Animal & $\begin{array}{l}\text { Mamíferos, aves, } \\
\text { répteis, anfíbios }\end{array}$ & perigo & \\
\hline & Natureza & $\begin{array}{c}\text { Árvores, terra plantas, } \\
\text { flores }\end{array}$ & & \\
\hline & Homem/Natureza & & Desmatamento; destruição & \\
\hline & Homem/Animal & & $\begin{array}{l}\text { Matar animais para fazer } \\
\text { casacos, bolsas, etc. }\end{array}$ & \\
\hline & Animal/Natureza & & Cadeia alimentar & $\begin{array}{c}\text { Moradia; } \\
\text { plantas }\end{array}$ \\
\hline & Homem/Animal/Natureza & & $\begin{array}{c}\text { Destrói a natureza e os } \\
\text { animais }\end{array}$ & \\
\hline
\end{tabular}

Fonte: Própria.

O aluno 13 destaca que: “A relação do homem com a natureza no meu ponto de vista não é muito bom porque tem muita poluição e desmatamento e com os animais a muita pesca exagerada e caça" e assim, responsabiliza o homem por estes fatores negativos. Seu diagrama de associações é interessante, pois ele não define intersecções para as interações entre homem - animais - natureza. A Figura 03, revela suas associações. A repetição da palavra desmatamento indica seu entendimento da relação com a natureza; com os animais esse entendimento é ilustrado por: inteligência, caça, cadeia alimentar, pecuária; e da relação de todos: deus e procriação. Entretanto, estas relações não se mostram evidentes, pois, a conexão entre as mesmas não foi realizada com clareza. Ou o aluno não entendeu a atividade, ou ele acredita que homem - animais e natureza não se relacionam. 
Figura 3. Associação realizada pelo aluno 13

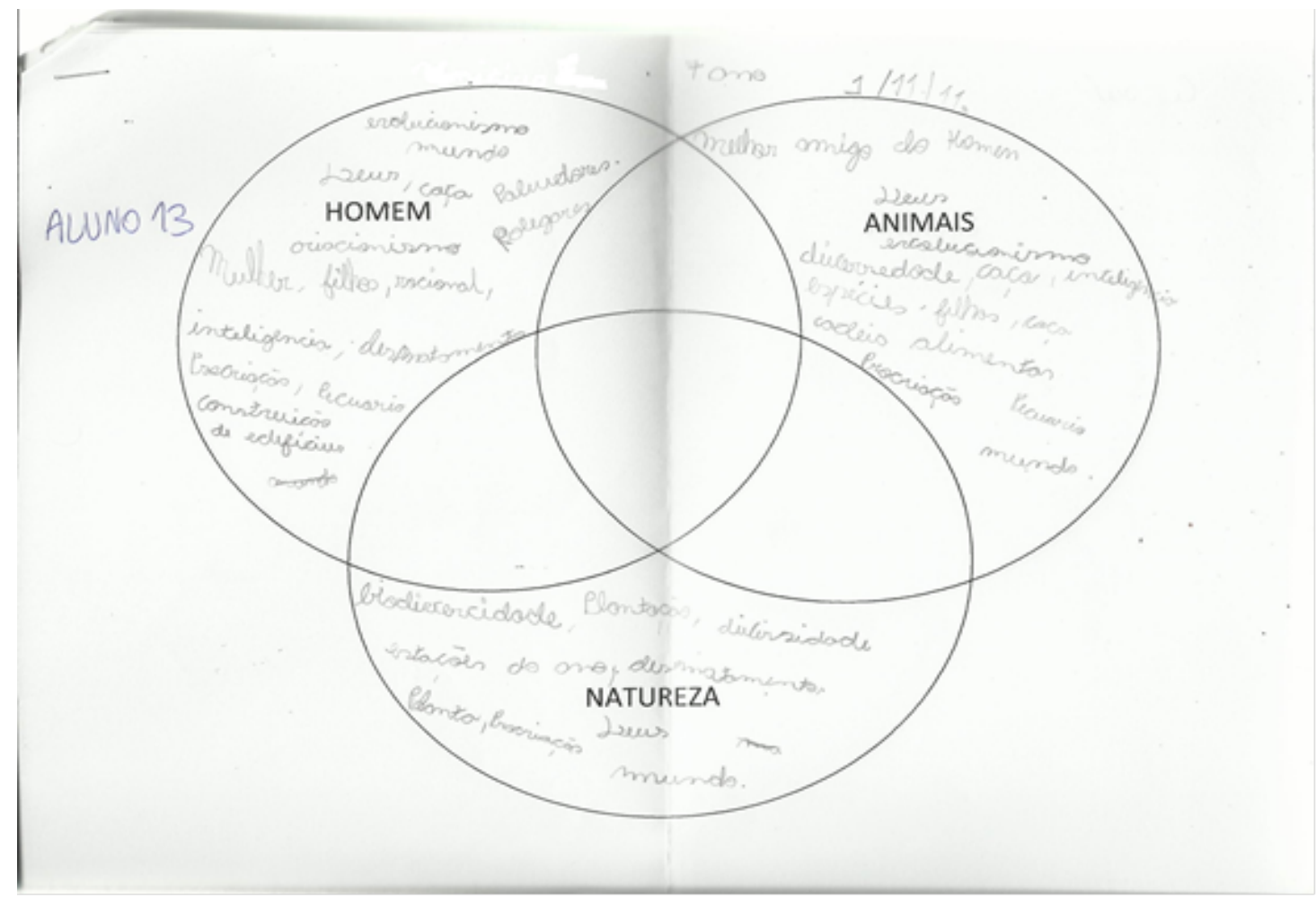

Fonte: Própria.

O aluno 14 diz que: "O mundo é formado por uma variedade de coisas, entre elas, os seres vivos. Todos os seres vivos têm uma diversidade de espécies. " Sua visão de desmatamento atinge apenas a natureza, e não aos animais, conforme demonstra a Figura 04; a relação comum a todos é exatamente a das espécies, como ele explica em sua fala, mas se esta é comum, como o impacto ambiental não atingiria os animais? O ciclo se relaciona apenas com a natureza/ animais, excluindo o homem desta interação, e ainda o homem demonstrar ter uma relação afetuosa e possivelmente harmônica com os animais domésticos, ou mais precisamente o cachorro citado como "melhor amigo do homem". A relação homem/ animais domésticos é algo artificial visto que, foi o próprio homem quem ao longo da história vem selecionando as espécies e criando novas raças para preencher suas diferentes relações de amizade e companhia. 
Figura 4. Associação realizada pelo aluno 14



Fonte: Própria.

O aluno 17 diz que: "Eu acho essa relação boa. ", mas essa resposta não confere com a análise e organização de suas associações, como segue demonstrado abaixo no quadro 6.

Quadro 6 - Tabela de respostas organizadas do aluno 17

\begin{tabular}{|c|c|c|c|c|}
\cline { 2 - 5 } \multicolumn{1}{c|}{} & \multicolumn{3}{c|}{ Indicadores } \\
\cline { 2 - 5 } \multicolumn{1}{c|}{ Classificação } & Harmônico & Desarmônico & Neutro \\
\hline Temas & Homem & & Poluidores & \\
\cline { 2 - 5 } & Animal & & Melhor amigo do homem & \\
\cline { 2 - 5 } & Natureza & & Desmatamento & \\
\cline { 2 - 5 } & Homem/Natureza & & Destrói a natureza & \\
\cline { 2 - 5 } & Homem/Animal & Espécies & & \\
\cline { 2 - 5 } & Animal/Natureza & & & \\
\cline { 2 - 5 } & Homem/Animal/Natureza & ciclo & & \\
\hline
\end{tabular}

Fonte: Própria.

O aluno 17 de outra forma poderia afirmar que a relação entre os três é boa para o homem, entretanto ele não faz uso de expressões utilitaristas. Ele entende que os ciclos se relacionam com todo o planeta, e portanto (re)insere o homem no ambiente. Ambiente poluído, desmatado e com a destruição da natureza proporcionada por ele mesmo. 
Entre outras frases escritas, cabe destacar esta separação do humano do ambiente e dos animais, quando, o aluno 10 diz que: "Os homens fazem parte do grupo dos animais e os animais fazem parte da natureza. Os animais e natureza são prejudicados, com o desmatamento e a caça; e são também beneficiados, pois os homens que plantam e cuidam de alguns animais dando à eles alimentação e também uma casa. " Nesta perspectiva, apenas o homem influencia e não é influenciado sendo um ser à parte.

O que discutimos aqui é a necessidade de contextualização entre os temas e da (re)inserção do homem no ambiente, para que as leituras de mundo possam compreender a relação causa/ consequência das atitudes do homem e de razões morais que movem suas ações. Em geral, nesta turma foi representada a associação entre os três temas pelas palavras criacionismo, e (bio)diversidade.

\section{O terceiro ano e o debate econômico}

As etapas para a realização da atividade foram aplicadas para a turma do terceiro ano do ensino médio da mesma maneira que foi aplicada no sétimo ano. Eram onze alunos em sala, e da mesma maneira que no sétimo ano, durante o brainstorm, ergueu-se um debate, dessa vez sobre consumismo e capitalismo. Diferentemente de visões mais críticas acerca do assunto, os alunos se manifestaram de forma positiva ao capitalismo e consumo, ainda que confundiam os termos consumo e consumismo. Essa lógica foi discutida na turma porque alguns poucos alunos se manifestaram contrários ao capitalismo, porém a maioria ou não tinha posição definida ou era a favor. É necessário lembrar que a escola é uma escola particular, e recebe alunos de alto poder aquisitivo. Este viés para o debate dificilmente seria obtido nas classes oprimidas ou nas escolas públicas e me surpreendi com esta realidade, quando apenas uma voz disse que era o capitalismo era negativo. Portanto, para as análises ora capitalismo será fator influenciador positivo, ora neutro e ora negativo.

Além de "consumismo" e "capitalismo", "agricultura" e "cidade" foram situados nesse impasse para definir a razão de influência nas concepções de mundo. A Figura 5 demonstra a primeira etapa, o brainstorm e a classificação dos fatores quanto harmônicos/positivos, desarmônicos/negativos e neutros. 
Figura 5. Quadro com brainstorm realizado no terceiro ano do ensino médio

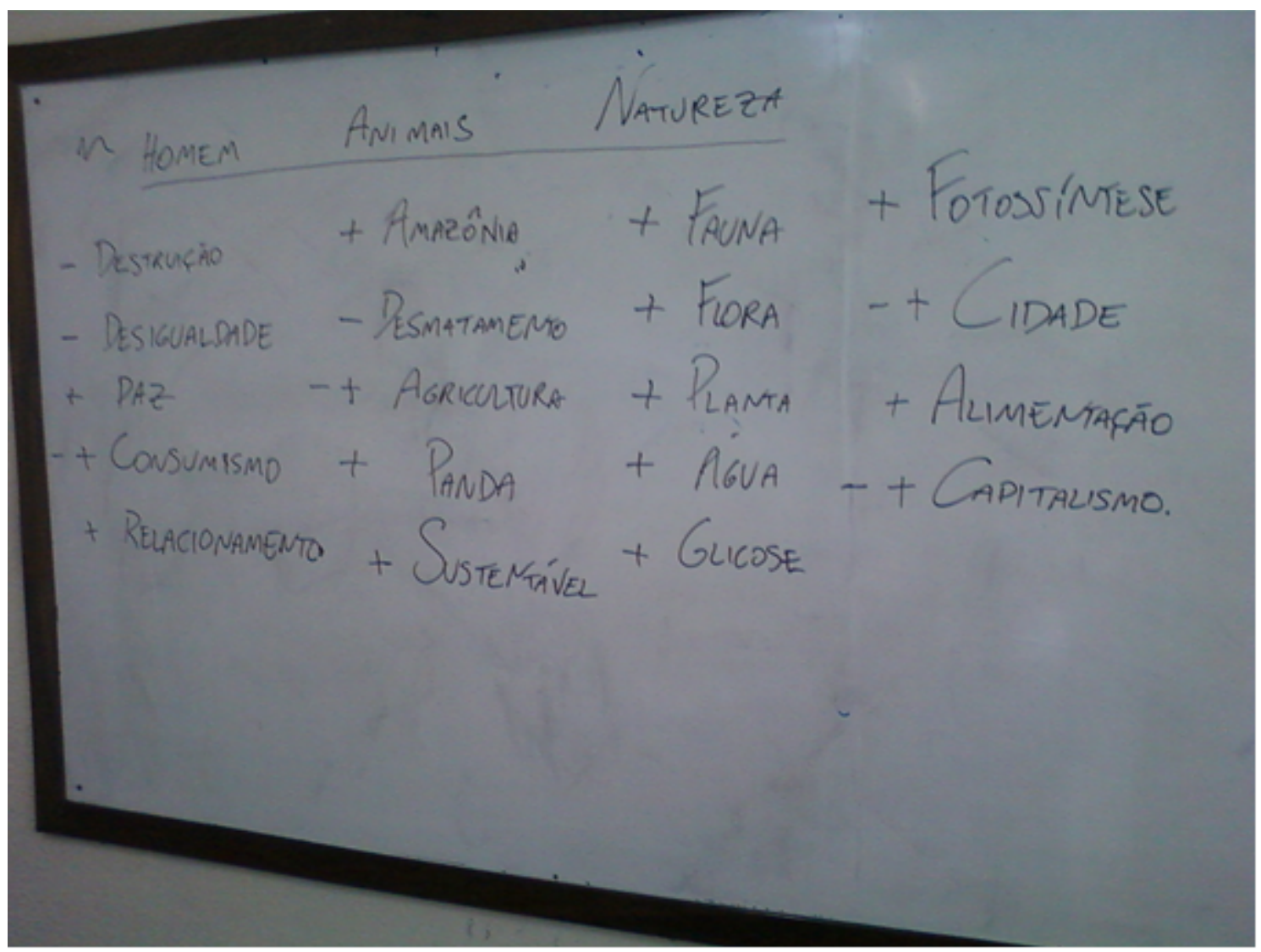

Fonte: Própria.

Conforme demonstra a figura, as palavras escolhidas pelos alunos da turma e representam relações positivas entre os temas são: paz, relacionamento, Amazônia, panda, sustentável, fauna, flora, planta, água, glicose, fotossíntese e, alimentação; relações negativas: destruição, desigualdade e, desmatamento; e tanto positivas quanto negativas são: consumismo, agricultura, cidade e capitalismo.

O aluno 30, em sua associação (Figura 6), caracteriza para o ser humano aspectos de desigualdade, e relaciona paz somente à natureza / animais. Este aluno explica em sua frase: "Os animais e a natureza viviam em um equilíbrio, não necessariamente pacífico, até serem escravizados pelo ser humano e sua suposta superioridade". A análise para essas associações demonstra a relação de dominação, hierarquização dos humanos e responsabilidade dos humanos para com a natureza. 
Figura 6. Associação realizada pelo aluno 30



Fonte: Própria.

Sobre a instrumentalização da natureza, cabe citar Ronulfo Vargas (2009):

O tratamento instrumental de escravos é análogo à relação que existe entre o homem e a natureza para fins produtivos. No processo de trabalho, o homem está diante da natureza como sujeito ao objeto, e vê nele um único recurso, que pode ser explorado em termos de necessidades e interesses. (VARGAS, 2009, p.17).

Essa turma manifestou no material das análises essa visão descontextualizada. Como diz o aluno 28: "Os homens, os animais e a natureza sempre vão se relacionar em pontos bons e ruins". Porém, segundo Oliveira (1996), o paradigma relativista retoma o princípio de neutralidade. Esta imparcialidade nos conduz a não-ação, sendo a imparcialidade importante referência aà manutenção do atual modelo econômico vigente. Outra fala que caracteriza esta imparcialidade é a do aluno 32, que diz: “Uma relação indispensável [ser humano / natureza / outros animais], como qualquer outra tem malefícios e benefícios", além disso, esta justificativa pode ser encarada como uma justificativa para a exploração e para se ausentar de responsabilidades.

A frase do aluno 25: "Atualmente, o homem apresenta controle sobre a natureza e os animais, onde criam relações através da ganância", representa mais uma vez a o distanciamento do homem da natureza. 0 aluno 36 também caracteriza esse distanciamento do ser humano 
da natureza com sua frase: "Os homens são amigos dos animais que vivem na natureza", ou seja, o homem é amigo dos animais que vivem na natureza, e dos outros não. Os outros animais, como diria Drummond em seu poema, seu conto, ele pela, come, aproveita bem o pelo, o couro e os ossos.

Há, entretanto um caso nessa turma que manifesta uma visão mais biocêntrica. É o caso do aluno 33, que elaborou a seguinte frase: "Na natureza o homem é o animal que promove mais relações desarmônicas". Ao analisar o seu quadro de associações, (Figura 7), percebemos que para ele há total relação entre o homem, natureza e animais.

Figura 7. Associação realizada pelo aluno 33

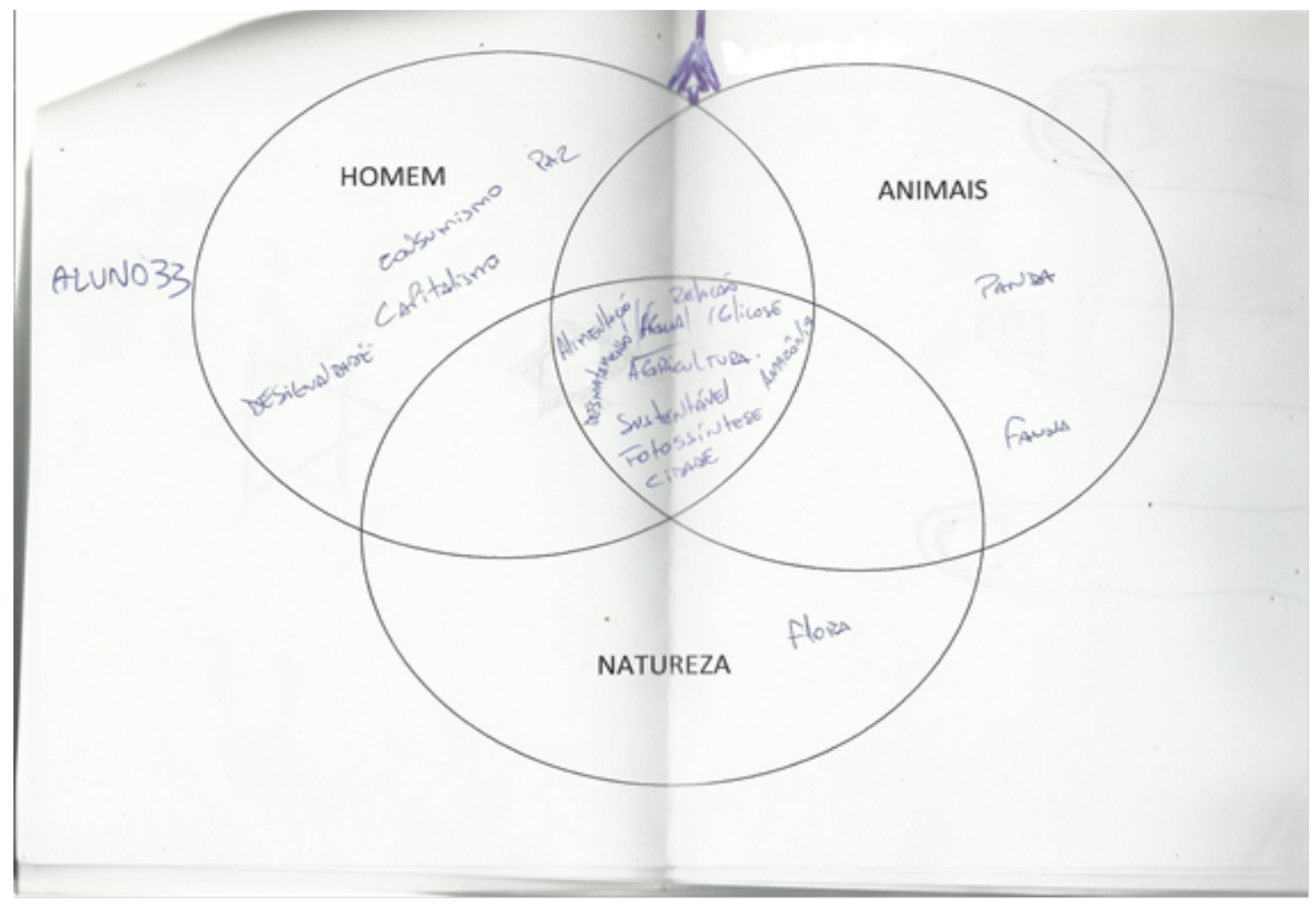

Fonte: Própria.

O aluno 34, escreveu que: "A relação entre homem, animais e natureza está muito degradada, pois o homem não sabe aproveitar de forma equilibrada o que a natureza oferece.". Outra vez fica claramente evidenciada a relação de domínio para com a natureza. E também na frase do aluno 25: "Atualmente, o homem apresenta controle sobre a natureza e os animais, onde criam relações através da ganância.". Sobre a utilização dos serviços ambientais, cabe citar Franco (2006:7): o valor não está nas comunidades animais e vegetais em si, o valor 
atribuído a essas espécies só adquire importância quando elas proporcionam benefícios aos homens.

A fim de expandir as reflexões ambientais de forma mais crítica assim como a questão da utilidade dos animais, entende-se que é necessário acompanhar a turma por mais tempo e trabalhar sucessivas atividades sobre a temática e entender a humanização do homem a partir da (re)inserção dele no ambiente e de sua atuação através da equidade moral para com os animais e a natureza. Por fim, cabe destacar a fala da orientadora educacional e psicóloga da escola, que diz:

aqui a escola, ela tem essa preocupação, dentro dessa pedagogia [waldorf] eu percebo que há uma forma muito doce de lidar com as crianças, muito... de respeitar o tempo de cada um (...) e eles tem esse contato com a natureza até pela própria escola (...) como é que isso reverbera nas crianças? Claro que tem reverberação positiva. A gente percebe. As crianças daqui às vezes são muito conscientizadas, até nos [casos de] portadores de necessidade especial, por exemplo, (...) agora, quanto à questão da dominação da natureza e dominação dos animais eu acho que isso aí todas as escolas querem colaborar pra que isso não aconteça, mas elas... não conseguem colaborar, porque isso é uma coisa do sistema. (...) eu to me lembrando livro Casa-Grande e Senzala, que o Gilberto Freyre fala da relação dos brasileiros com os animais, como se [eles] fossem alguém da família. Claro que quando eu li aquilo (...) eu adorei(...) só que depois (...) eu vi que talvez aqui [neste caso] seja onde se opera com maior ferocidade a questão da dominação, porque não tem como você destruir um sentimento tão positivo desse homem que acha botar um tatu pra dormir um tatu dentro de casa de casa é bom... a minha mãe tinha um tatu! (...) claro que aquele tatu não deve ter vivido a quantidade de anos que ele viveria (...) e não procriou, foi contra a espécie nesse sentido porque ele não teve parceira (...) agora, na cidade, como é isso? A criança vai lá no zoológico e acha o macaco estressado bonito. A criança vai na floresta, quer preservar o tatu-num-sei-o-que que tem lá, mas ele... dá coelho de presente no dia de aniversário. Tá na maior moda dá bichinho vivo aí. Os artistas dão... e o bichinho fica jogado (...) é uma matança (...) por um outro lado, quando eu digo que isso é do sistema, se não se inclui o homem também na preservação, também não adianta. Que que adianta... é uma coisa que eu observo, você corta umas árvores dá ibope, se mata todo dia as pessoas pelos motivos mais tortos que existe e aquilo cai no esquecimento rápido. Sem contar que o próprio sistema tá matando muita gente todo dia tá matando de [falta] emprego, tá matando por falta de condição de vida, tá matando por falta de liberdade, entendeu? (...) voltando à questão da escola, eu só acho que a escola vai ajudar de fato o aluno quando ela trouxer essas questões.

\section{CONCLUSÕES}

Observou-se que a abordagem sócio-construtivista ao longo das séries vai se diluindo, o que parece ser naturalizado pelas cobranças de aprovação na universidade. Apesar de poucas, observaram-se algumas contextualizações dos conteúdos com a 
realidade, porém, a relação conteúdo - conteúdo pode ser interpretada como uma lacuna, principalmente para as áreas celulares, por dificuldade de contextualização.

As turmas do sexto e sétimo ano dessa escola são compostas em sua maioria por alunos que estão desde a educação infantil na escola e participaram do processo de implementação da Pedagogia Waldorf na escola, o que pode significar um resultado positivo para esta nova abordagem. Sobre a concepção de mundo dos alunos da escola, cabe destacar que os alunos do sexto e sétimo ano atribuíram valores de equidade centrados na vida sendo fator comum entre homem, natureza e animais, diferentemente dos alunos do terceiro ano do ensino médio. Esta pode ser uma evidência do sucesso da implementação da Pedagogia Waldorf que tem exatamente como um de seus objetivos essa valoração à vida.

Sabendo que as turmas comparadas possuem diferentes perfis de grupo, faixa etária e formação, sob o aspecto filosófico-pedagógico, conclui-se que serão necessários outros trabalhos com objetivo específico para determinar a influência da Pedagogia Waldorf e do Ensino Sócio-Construtivista, comparado com o ensino tradicional, quanto a relação de equidade entre humanos e outros animais e a reinserção do homem à natureza, à valoração da vida e humanização dos alunos. E ainda, faz-se necessária ampla atuação do professor na formação dos alunos sendo autor de suas próprias aulas e atividades e promovendo debates além dos conteúdos, mas buscando uma formação crítica dos educandos. $\mathrm{E}$ a afetividade também se configura como importante fator para o processo de ensino-aprendizagem, principalmente para aqueles alunos da Educação Inclusiva.

Foi observado, entre os alunos dos anos iniciais do ensino fundamental II, recémsaídos do ensino waldorf, uma formação humanística demonstrada por maior contextualização das relações humanas junto aos elementos da naturez e preocupação com o bem-estar animal. Nos anos finais do ensino médio, a visão de mundo se afasta de uma visão naturalista indo em direção ao individualismo, quando ocorre uma formação para o vestibular. Cabe destacar que a implementação Waldorf nessa escola é recente, sendo esta conclusão aqui apresentada para os anos finais do ensino médio referente a alunos que não obtiveram a formação Waldorf. 


\section{REFERÊNCIAS}

BACHINSKI, Róber Freitas.. Quando o mito se torna verdade e a ciência, religião. Cadernos IHU Idéias (UNISINOS), v. 117, p. 1-31, 2009.

BALBI, J. C. S.. A pesquisa qualitativa e a história de vida. Vilhena. Rondonia. 1999.

BARBOSA, M. T.. Educação ambiental popular: a experiência do centro de vivência agroecológica CEVAE-TAQUARIL. Dissertação de Mestrado. UFMG. Belo Horizonte/Minas Gerais. 2002. Disponível em: < http://www.bibliotecadigital.ufmg.br/dspace/bitstream/handle/1843/MPBB-

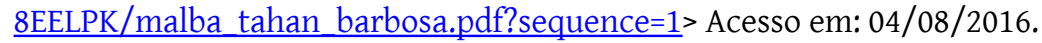

BARTLETT, S. J.. Raízes da resistência humana aos direitos dos animais: Bloqueios psicológicos e conceituais. Revista Brasileira de Direito Animal. Salvador, BA: Evolução. Vol. 2, n.2 2007. Disponível em: < http://www.portalseer.ufba.br/index.php/RBDA/article/view/10357/7419> Acesso em: 04/08/2016.

BIGNOZZI, S. M.; BARROS, L.. Aspectos fundamentais da pedagogia Waldorf. 10 Congresso de iniciação científica. Universidade de Santo Amaro. São Paulo. 2007.

BOFF, Leonardo. A Opção-Terra: a solução para a Terra não cai do céu. Record. Rio de Janeiro. 2009

BONOTTO, D. M. B. SEMPREBONE, A.. Educação ambiental e educação em valores em livros didáticos de ciências naturais. Ciência e Educação, v.16, n.1, p131-148. 2010. Disponível em: < http://www.scielo.br/pdf/ciedu/v16n1/v16n1a08.pdf> Acesso em: 04/08/2016.

CARRETERO, Mario. Introducción a la psicología cognitiva. Aique Grupo Editor, 1997.

DESCOLA, Philippe. Par-delà nature et culture. Paris: Gallimard, 2005.

DOVAL, L. Direitos dos aimais: uma abordagem histórico-filosófica e a percepção de bem-estar animal. Monografia de conclusão de graduação em medicina veterinária. Unversidade do Rio Grande do Sul. Porto Alegre. 2008. Disponível em: < http://www.lume.ufrgs.br/handle/10183/16438> Acesso em: 04/08/2016.

DRUMMOND, Carlos de. De notícias e não notícias faz-se a crônica. Rio de Janeiro, José Olympio, 1975.

FREIRE, P.. Pedagogia da Autonomia. Publicação original em 1996. Versão digitalizada. 2002.

FONSECA, L. C. S.. Religião popular: o que a escola pública tem a ver com isso? - pistas para repensar o ensino de ciências -. Tese de Doutorado. Universidade Federal Fluminense. Niterói. 2005. Disponível em: < http://bdtd.ibict.br/vufind/Record/UFF_6c81af36819d535b417faf03673c2f1c > Acesso em: 04/08/2016.

FRANCIONE, G. L.. Introduction to animal rights: your child or the dog? Temple University Press. Philadelphia. United States. 2000.

GAUTHIER, Jacques. O corpo, caminho para tornar mais transcultural a sociopoética. ENTRELUGARES, v. 2. 2009.

GUIMARÃES, Mauro. A formação de educadores ambientais. Campinas. São Paulo. Editora Papirus. 2004

JACOBI, P.. Educação ambiental, cidadania e sustentabilidade. Cadernos de Pesquisa, n. 118, p. 189-205, março. 2003. Disponível em: < http://www.scielo.br/pdf/cp/n118/16834.pdf > Acesso em: 04/08/2016.

LEVAI, Laerte.. Os animais sob a visão da ética. Congresso Ambiental do Ministério Público. Campos de Jordão. 2001. Disponível em: http://www.mp.go.gov.br/portalweb/hp/9/docs/os__animais__sob_a__visao_da_etica.pdf> Acesso em: 04/08/2016.

. Direito dos Animais. Editora Mantiqueira, 2a . edição, Campos do Jordão: 2004 
LOUREIRO, C. F. (org.)... [et al.]. A questão ambiental no pensamento crítico: natureza, trabalho e educação. Rio de Janeiro: Quartet. 2007

LOVELOCKE, J.. Gaia: Um novo olhar sobe a Terra. Lisboa: Ediçõees 70. 1989.

MUNIZ, Tiago Silva Alves. BACHINSKI, Rober. Da Coerção ao Uso de Animais no Ensino e na Pesquisa. Educação e Cidadania, v. 1, p. 82, 2012. Disponível em: < http://seer.uniritter.edu.br/index.php/educacaoecidadania/article/view/538 > Acesso em: 04/08/2016.

NACONECY, Carlos Michelon.. Ética e Animais: um guia de argumentação filosófica. EDIPUCRS, 2006.

NUSSBAUM, M. C.. Book Review: Animal Rights: The Need for a Theoretical Basis, 114 Harv. L. Rev. 1506, $1549,2001$.

REGAN, Tom. Jaulas Vazias: encarando o desafio dos direitos animais. Porto Alegre, Rio Grande do Sul. Lugano Editora. 2006.

REIGOTA, M.. O que é educação ambiental. Brasiliense, São Paulo, Brasil. 1991.

RYDER, Richard Dudley. Victims of science. The use of animals in research. Davis-Poynter Ltd., 1975.

no Ensino e na Pesquisa

Painism: A modern morality. Open Gate Press, 2001. Da Coerção ao Uso de Animais

Putting Morality Back Into Politics. Vol. 48. Andrews UK Limited, 2015.

SARLET, I. W.; FENSTERSEIFER, T.. Algumas notas sobre a dimensão ecológica da dignidade da pessoa humana e sobre a dignidade da vida em geral. Revista Brasileira de Direito Animal. Ano 2 - Número 3 - jul/dez 2007. Disponível em: <http://www.portalseer.ufba.br/index.php/RBDA/article/view/10358/7420> Acesso em: $13 / 07 / 2016$.

SINGER, Peter. Animal Liberation: A New Ethics for Our Treatment of Animals. New York: Random House, 1975.

STEINER, Rudolf; LANZ, Rudolf; CARDOSO, Jacira. A arte da educação: 0 estudo geral do homem, uma base para a pedagogia:(Curso de Antropologia Geral para professores Waldorf); catorze conferências, proferidas em Stuttgart de 21 de agosto a 5 de setembro de 1919, por ocasião da fundação da Escola Waldorf Livre. Antroposofica, 2007.

TRIVIÑOS, J. C.. Introdução à pesquisa em ciências sociais: a pesquisa qualitativa em educação. São Paulo: Atlas, 1987. 